\title{
A Study on the Relationship between EFL Learners' Nationality and Language Learning Motivation
}

Seyyed Mohammad Reza Amirian*, Najme Komesh

Department of English Language and Literature, Hakim Sabzevari University, Sabzevar, Iran

Corresponding Author: Seyyed Mohammad Reza Amirian, E-mail: smr.amirian@gmail.com

\section{ARTICLE INFO}

Article history

Received: November 01, 2017

Accepted: January 06, 2018

Published: March 01, 2018

Volume: 7 Issue: 2

Advance access: February 2018

Conflicts of interest: None

Funding: None

\begin{abstract}
The present study was an attempt to investigate the relationship between nationality of Persian, Arab and Turk EFL learners and their motivation toward English language learning. To perform this, 120 Persian, Turk and Arab EFL learners studying at English Preparatory school in Eastern Mediterranean University in Cyprus were selected to participate in this research. In order to measure the EFL learners' motivation toward learning English, a motivational questionnaire including 29 items was administrated to all three groups of the present study. At last, in order to find any relationship between nationality of EFL learners and their language learning motivation and to examine any differences among Persian, Turk and Arab EFL learners in terms of language learning motivation, a chi-square and an analysis of variance (ANOVA) were run. The results revealed that there was relationship between nationality of EFL learners and their language learning motivation. Moreover, there was significant difference between nationality of Persian, Turk and Arab EFL learners and their language learning motivation.
\end{abstract}

Key words: Nationality, EFL Learners, Language Learning Motivation

\section{INTRODUCTION}

The learners in English as foreign language (EFL) context learn the language in a formal classroom setting without opportunities to use the language outside the classroom. In other words, the EFL learners have few opportunities to talk with native speakers of English in society. It happens in a country where English does not play a significant role in internal communication (Brown, 2007; Richards \& Rodgers, 2001; Richards \& Schmidt, 2010; Richards \& Renandya 2002). Therefore, EFL context is different from English as a second language (ESL) context in which the language is necessary for everyday life or in a country in which English plays an important role in education, business, and government. Based on the distinctions between EFL and ESL settings, nationality of language learners should be taken into consideration in the process of foreign language learning. Nationality is defined as the status of belonging to a particular nation, whether by birth or naturalization (dictiobnary. com, 2017). In the present study, the relationship between nationality of EFL learners and language learning motivation was investigated.

Language learning motivation was also a prominent issue in EFL or ESL context. In order to improve the EFL learners' language proficienc, English teachers should encourage and motivate their EFL learners in the process of language learning (McNinch, 1997; Ngeow, 1998). One of the most important problems in the field of language learning and teaching is how to motivate the EFL learners to engage in foreign language learning (Ngeow, 1998). The best teachers are those who motivate their learners to participate in learning process and learn actively (Dornyei, 2001; Vandergrift, 2005). Motivation is described as a motivating power in any situation that leads to action (Dornyei \& Otto, 1998, Richards \& Schmidt, 2010). Motivation is a prerequisite for learning, plays an important role in foreign/second language learning. It is highly complex and multilayered issue in learning but there are some ways to motivate EFL/ESL learners in classroom. Dornyei (2005) stated that deficiencies in "language aptitudes and learning conditions" can be healed by motivating foreign language learners. "The dynamically changing cumulative arousal in a person that initiates, directs, coordinates, amplifies, terminates and evaluates the cognitive and motor processes whereby initial wishes and desires are selected, prioritized, operationalized, and (successfully or unsuccessfully acted)" (Dornyei \& Otto, 1998, p. 65).

One of the problems dealt with in this study is the unknown relationship between the nationality of Persian, Turk and Arab EFL learners and their language learning motivation. Thus, it is considered as one of the novel issues which should be taken into account by the specialists in the field of study. Longman Dictionary of Contemporary English (2017) describes motivation as "eagerness and willingness to do something without needing to be told or force to do it". Despite the bulk of research having been conducted on 
the importance of motivation in the process of language teaching and learning, what is deemed neglected in numerous researches is the necessity of exploring the relationship between nationality of Persian, Turk and Arab EFL learners and their language learning motivation. Therefore, in order to fill the gap, the present was constructed

\section{RELATED LITERATURE}

Motivational studies are essential to promote the educational goals of any curriculum planning. Curriculum developers and educators have tried a lot to find out how to best motivate language learners in order to promote English language learner's proficiency and learning in any educational context. Some scholars, Dörnyei, (1994); Dörnyei \& Ushioda, (2011), and Gao \& Lamb, (2011) have stated that the success of language learners to achieve educational goals can be accomplished through one of the most highlighted factor that is motivation. Although motivational aspect of education has got centrality in many researches and articles, it is still one of the challenging factors to deal with. Different scholars have considered motivation from different perspectives. In the following, different motivational studies are presented and the ending paragraph will present a gap in the literature that is overlooked by lots of scholars.

Attitudes and motivation of EFL learners was studied by Alshaar (1997). The Gardner's (1985) attitude and motivation translated test battery was used as the instrument. Obtained results from the questionnaire revealed that there were significant correlations between attitudes and motivation and learning English as a foreign language. Moreover, the findings indicated that there was a significant level of English class anxiety upon which future investigations were suggested.

In another study, Papi and Teimouri (2012) investigated the Iranian EFL learners' evolution of motivation. The study was conducted with 1,041 Iranian EFL learners through a survey questionnaire. They reported that as the students grow up and go to higher levels "the ideal L2 self, L2 learning experience, instrumentality promotion, attitudes towards L2 culture and community improved". On the other hand, some preventing characteristics "i.e. the ought-to L2 Self, family influence, instrumentality-prevention" decreased as the students grow up.

In the field of motivational studies gender, proficiency and its interaction with intrinsic or extrinsic motivation has been investigated by Hassani (2005). He reported that the interaction among motivation, gender, and level of English proficiency was not significant. Moreover, there are other studies that investigated the differences between the students studying in different levels and different ages for example in one study, Williams, Burden and Lanvers (2002) studied differences in 228 British students' motivation for learning French and German. Finally, they found out that as the students grow older, their motivation level confronts decrease. In a meta-analysis of the studies conducted by Gardner and his associates, Masgoret and Gardner (2003) considered age as the moderating effect on the relationship of L2 achievement to a number of other factors which can be motivation- al or attitudinal. Thus these factors include attitudes toward "learning situation, integrativeness, and motivation". The results revealed that age has not any effect on these issues.

In another research study, Papi (2010) took the advantage of investigating what Dornyei's in 2005 and 2009 pinpointed the motivational self-system, anxiety and English language learning effort. Dornyei proposed a theoretical model (the ideal L2 self, the ought to self, and the L2 learning experience and based on that some studies have been done. Papi (2010) took this theoretical model and he found that all the variables in the model significantly affected and contributed intended effort. On the other hand, the ideal L2 self and the L2 learning experience decreased students' English anxiety, the ought to L2 self significantly made them more anxious

MacIntyre, Baker, Clément and Donovan (2002) investigated the motivational characteristics of the students in a French immersion program. Results of the study revealed that the student's level of motivation between Grades 7 and 8 dropped. Moreover, Soltani (2013) tried to investigate the effect of ethnic background on Iranian EFL learners' intercultural sensitivity. So, many ethnic groups, 382 students, belonging to Azeri, Farsi, Kurdish, Lori and Baluchi ethnic groups were randomly selected to participate in this research. Intercultural Sensitivity Scale adapted from Chen and Starosta's (2000) was used for collecting raw data. The results indicated there was a strong relationship between intercultural sensitivity and ethnic background. In addition, obtained results revealed that there was a relationship between the two, proved the strongest in Kurdish and the weakest in Azeri ethnic groups.

Bernard (2010) was another researcher in the field of study who treated motivation as both a dependent and an independent function of classroom activities. The focus of Bernard's study was many types of motivation, motivation about the language, the class, confidence, external motivation, whether the class feels required, and self-reported motivation. Results of the study revealed that one of the most important motivations in predicting the outcomes was motivation about the language which was along with fun activities and activities that promote language use about students' own lives and interests. Likewise, Anjomshoa and Sadighi (2015) conducted a research study on the importance of motivation in second language acquisition. According to Anjomshoa and Sadighi (2015), there should be positive atmosphere in class and that positive atmosphere is not possible without student's motivation. They concluded that the language teachers and researchers should pay special attention to demotivating factors in order to overcome them as the concept of motivation in EFL settings is so prominent. Thus, Mostafaei Alaei and Ghamari (2013) investigated the relationship between EFL learning and national identity. Moreover, the authors tried to find out the relationship between language motivation types and national identity. Obtained results indicated that claims over the harmful social effects of EFL learning were not arguably significant. Moreover, among the eight language motivation types, going abroad and social responsibility were correlated with national identity.

Although numerous studies have investigated motivation from different perspective as it was the center of attention 
to many scholars, the researcher confronted with a large gap in the area of language teaching and learning in a context that different nationality groups were studying English as a foreign language. This study investigates the relationship between nationality of EFL learners and their language learning motivation. The researcher hopes that the findings and result of the current study will provide researchers with insightful comments about the EFL learners' motivation and their nationality.

\section{Research Questions and Hypotheses}

RQ1: Is there any relationship between nationality of EFL learners and their language learning motivation?

RQ2: Is there any significant difference between nationality of EFL learners and their language learning motivation?

To answer the related questions, following research null hypotheses were formulated:

H01: There is no relationship between nationality of EFL learners and their language learning motivation.

H02: There is no significant difference between nationality of Persian, Turk and Arab EFL learners and their language learning motivation.

\section{METHODOLOGY}

\section{Participants}

The participants of the present study were 120 Persian, Turk and Arab EFL learners studying at English Preparatory school in Eastern Mediterranean University in Cyprus. Moreover, numerous Russian, Georgian, Kazak, Chinese, and Kyrgyz learners were studying English as foreign language in the university. Before entering the English preparatory school, all students should participate in IELTS exam for placing the learners in appropriate levels. The students are placed in their appropriate levels which are elementary, inter and upper intermediate. Based on English language level for entry to the university which mainly measured by IELTS exam, the participants were considered as intermediate and upper-intermediate EFL learners. They were all passing English courses in academic year 2015-2016. All of the participants were in the age ranging from 18 to 29 years old.

\section{Instrument}

\section{Language learning motivation questionnaire}

In order to understand about the EFL learners' motivation toward learning English, motivational questionnaire (adapted from Attitudes/Motivation Test Battery; Gardner, 1985), including 29 items was used. The questionnaire was a Likert-type scale coded on a 5-point scale. Those learners' responses that were strongly agree for an item received five points and those learners' responses that were strongly disagree received one point. The reliability of the language learning motivation questionnaire was estimated which showed acceptable ranges (Table 1).
Table 1. The Cronbach's alpha for Language learning motivation questionnaire

\begin{tabular}{lcccc}
\hline & N & M & SD & Cronbach's alpha \\
\hline Persian & 40 & 3.8546 & 0.88992 & 0.801 \\
Turk & 40 & 3.0584 & 0.89654 & 0.752 \\
Arab & 40 & 2.8546 & 0.86485 & 0.794 \\
\hline
\end{tabular}

\section{Procedure}

In order to conduct this study, the language learning motivation questionnaire was administered to the whole population in order to examine the relationship between nationality of Persian, Turk and Arab EFL learners and their language learning motivation. The participants were asked to complete information about name and age on the papers and they were also asked to fill in a consent letter as it was important for the researcher that the participants take part in the study wholeheartedly (appendix II). They were also notified that the test and the scale of this study would have no influence on their university-related achievements and that they were asked to be as honest as possible. Moreover, the participants were supposed to fill the questionnaire in accordance with what extent they agree with the questionnaire's statements. In order to do this, a Likert scale (rating scale or the Likerttype scale) was used. The students had 30 minutes time to answer the test's items.

\section{Design}

The present study was carried out through a correlative research. It is a type of non-experimental research in which the researcher investigates the relationship between two or more naturally occurring variables. In this study, the researcher investigated the relationship between nationality of Persian, Turk and Arab EFL learners and their language learning motivation.

\section{Data Analysis}

The descriptive statistics including mean, standard deviations, maximum and minimum of the scores were calculated. In order to answer the first research question and find any relationship between nationality of EFL learners and their language learning motivation, a chi-square was used. Moreover, analysis of variance (ANOVA) was used in order to examine any differences among Persian, Turk and Arab EFL learners in terms of language learning motivation.

\section{RESULTS AND DISCUSSION}

\section{Reliability Statistics}

Cronbach's alpha which is the most common measure of internal consistency was used to reveal the consistency of the questionnaire. The values of Cronbach's Alpha for the instrument used in this study showed acceptable internal consistency of reliability (Table 1) for different nationality groups. 


\section{Descriptive Statistics}

The results of the Table 2 showed that Persian, Turk and Arab EFL Learners' mean scores in the language learning motivation questionnaire were 3.8546, 3.0584 and 2.8546 respectively. Persian EFL learners have the highest mean and Arab EFL learners have the lowest. The result reveals that Persian EFL learners, reporting the highest mean, have the highest motivation in learning English as a foreign language. Moreover, Arab EFL learners reported the lowest mean which reveals that they have the lowest motivation in learning English as a foreign language. Turk EFL students have moderate level of motivation in comparison with Arab and Persian EFL students.

\section{Teasing Hypothesis One}

There is no relationship between nationality of EFL learners and their language learning motivation. In order to test this hypothesis a chi Square test was run (Table 3).

Based on the results from the analysis of chi-square, the significance level was less than the error value 0.05. Chisquare analysis revealed that motivation and nationality of EFL learners are dependent. Therefore, there is relationship between nationality of EFL learners and their language learning motivation. In other words, the related research null hypothesis is rejected. Moreover, it can be understood that motivation does have an important role in the distribution of different nationality groups which should be taken into account by educators (Table 4).

Nelson (1984) has mentioned that Gamma coefficient needs a non-parametric correlation which requires ordinal data. In order to find out the possible correlation between the nationality of EFL learners and their language learning motivation a gamma coefficient correlation was run. Gamma correlation was equal to 0.393 which indicated the positive

Table 2. Descriptive statistics for the EFL Learners' scores

\begin{tabular}{lccc}
\hline & $\begin{array}{c}\text { Persian EFL } \\
\text { learners }\end{array}$ & $\begin{array}{c}\text { Turk EFL } \\
\text { learners }\end{array}$ & $\begin{array}{c}\text { Arab EFL } \\
\text { learners }\end{array}$ \\
\hline $\mathrm{N}$ & 40 & 40 & 40 \\
Mean & 0 & 0 & 0 \\
Standard & 3.8546 & 3.0584 & 2.8546 \\
deviation & 0.88992 & 0.89654 & 0.86485 \\
Minimum & 1 & & \\
Maximum & 5 & 1 & 1 \\
\hline
\end{tabular}

Table 3. Chi square tests

\begin{tabular}{lccc}
\hline & Value & df & $\begin{array}{c}\text { Asymp. } \\
\text { Sig. (2-sided) }\end{array}$ \\
\hline Pearson Chi-square & $31.231^{\mathrm{a}}$ & 24 & 0.047 \\
Likelihood ratio & 36.860 & 24 & 0.045 \\
Linear-by-Linear Association & 8.754 & 1 & 0.003 \\
Number of valid vases & 120 & & \\
\hline
\end{tabular}

relationship between nationality of EFL learners and their language learning motivation.

\section{Testing Hypothesis Two}

There is no significant difference between nationality of Persian, Turk and Arab EFL learners and their language learning motivation. In order to investigate if testing hypothesis two is true or not One-Way ANOVA is run.

Based on the results from Table 5, the significance level is 0.009 and it is less than the error value 0.05 . Therefore, there is significant difference between nationality of Persian, Turk and Arab EFL learners and their language learning motivation. In other words, the second research null hypothesis was rejected.

Therefore, in order to control type 1 error for pairwise comparisons and to find out which group differs, the Least Significance Level (Fisher's LSD) is run (Table 6). So, LSD can be used to identify the statistical difference between pairs of means.

According to the results from Table 6, the significance level was less than the error value 0.05 . Therefore, there was significant difference between nationality of EFL learners and their language learning motivation. It should be noted that the language learning motivation of Persian EFL learners was greater than that of Turk and Arab learners. Moreover, Turk EFL learners' language learning motivation was greater than that of Arab learners.

The findings of the present study are in line with Alshaar (1997) who examined attitudes and motivation of second language learners in Kuwait. The findings were consistent with those of the other researchers': there are significant correlations between affective variables (attitudes and motivation) and learning a second language. Soltani (2014) also investigated the effect of ethnic background on Iranian EFL learners' intercultural sensitivity. Obtained results revealed that there was a strong relationship between intercultural

Table 4. Symmetric measures

\begin{tabular}{ccccc}
\hline & Value & $\begin{array}{c}\text { Asymp. } \\
\text { Standard } \\
\text { error }^{\mathrm{a}}\end{array}$ & Approx. T $^{\mathrm{b}}$ & $\begin{array}{c}\text { Approx. } \\
\text { Sig. }\end{array}$ \\
\hline $\begin{array}{c}\text { Ordinal by } \\
\text { ordinal } \\
\text { Gamma }\end{array}$ & 0.393 & 0.097 & 3.964 & 0.000 \\
$\begin{array}{c}\text { Number of } \\
\text { valid cases }\end{array}$ & 120 & & & \\
\hline
\end{tabular}

Table 5. One way ANOVA

\begin{tabular}{lccccc}
\hline & $\begin{array}{c}\text { Sum of } \\
\text { squares }\end{array}$ & df & $\begin{array}{c}\text { Mean } \\
\text { square }\end{array}$ & F & Sig. \\
\hline $\begin{array}{l}\text { Between } \\
\text { groups }\end{array}$ & 345.117 & 2 & 172.558 & 4.907 & 0.009 \\
$\begin{array}{l}\text { Within } \\
\text { groups }\end{array}$ & 4114.350 & 117 & 35.165 & & \\
Total & 4459.467 & 119 & & & \\
\hline
\end{tabular}


Table 6. Multiple comparisons (LSD)

\begin{tabular}{llccccc}
\hline (I) group & (J) group & Mean difference (I-J) & Standard error & Sig. & \multicolumn{2}{c}{ 95\% confidence interval } \\
\cline { 5 - 7 } & & & & & Lower bound & Upper bound \\
\hline \multirow{2}{*}{ Persian } & Turk & 1.22500 & 1.32600 & 0.007 & 1.8511 & 2.4011 \\
& Arab & $4.05000^{*}$ & 1.32600 & 0.003 & 1.6761 & 6.4239 \\
\multirow{2}{*}{ Turk } & Persian & -1.22500 & 1.32600 & 0.007 & -2.4011 & -1.8511 \\
& Arab & $2.82500^{*}$ & 1.32600 & 0.035 & 1.4511 & 5.1989 \\
& Persian & $-4.05000^{*}$ & 1.32600 & 0.003 & -6.4239 & -1.6761 \\
& Turk & $-2.82500^{*}$ & 1.32600 & 0.035 & -5.1989 & -1.4511 \\
\hline
\end{tabular}

sensitivity and ethnic background. Moreover, the researcher found that the relationship between the two proved the strongest in Kurdish and the weakest in Azeri ethnic groups. Papi (2010) took a model that subsumes the ideal L2 self, the ought to L2 self, and the L2 learning experience in Dornyei's (2005, 2009) L2 motivational self-system, as well as English anxiety and intended effort to learn English. Results revealed that all the variables in the model significantly contributed to intended effort; however, while the ideal L2 self and the L2 learning experience decreased students' English anxiety, the ought-to L2 self significantly made them more anxious

The findings of this research match with Mostafaei Alaei and Ghamari (2013) who explored the relationship between EFL learning and national identity. In addition, they attempted to find a relationship between language motivation types and national identity. The results revealed that claims over the harmful social effects of EFL learning were not arguably significant and it was found that among the eight language motivation types, going abroad and social responsibility were correlated with national identity.

\section{CONCLUSION}

The present study was an attempt to investigate the relationship between nationality of Persian, Turk and Arab EFL learners and their language learning motivation. Obtained results from the data analysis procedure revealed that there was relationship between nationality of EFL learners and their language learning motivation. Moreover, there was significant difference between nationality of Persian, Turk and Arab EFL learners and their language learning motivation.

The language learning motivation of Persian EFL learners was greater than that of Turk and Arab learners. Possibly, there are some reasons why Iranian EFL learners are motivated which are as follows:

a) Learning English makes it easier to communicate while abroad.

b) English is the closest to the world of having a global language.

c) Learning English facilitates communication with people from different countries.

d) Learning English improves career prospects.

e) Learning English makes working life easier.

Persian EFL learners are usually famous for high level of integration with a foreign language culture. Persian learners are possibly more motivated because they are in love of communicating with a native speaker spatially in a foreign country. Moreover, they are in love of understanding and integrating with a foreign culture.

\section{Implications and Suggestions}

The findings of the present study hold some important implications:

Based on the importance of motivation in the process of foreign/second language learning, the EFL teachers should pay special attention to language learning motivation as a vital prerequisite in order to develop their learners' foreign language learning.

The findings of the present study revealed that Turk and Arab EFL learners were less motivated in terms of foreign language learning. In view of that, Arab and Turk EFL teachers should use different ways in order to overcome the problem and improve their learners' foreign language learning motivation.

The findings of this study can encourage all language teachers and researchers to give due weight to EFL learners' language learning motivation and ethnic background as components of modern language teaching/learning.

Some practical suggestions in the light of the findings are presented as follows:

1. It was better to use a combination of quantitative and qualitative research method in further study although only quantitative analyses were employed in this research.

2. Other psychological factors such as self-esteem, personality traits, identity styles, and autonomy were not investigated in the present study. Possibly, studying the relationship between nationality of EFL learners and these variables may be useful to improve EFL learners' second/foreign language learning process.

3. Further research is suggested to use larger samples of both female and male participants to be able to generalize the findings to all EF learners.

4. The current study was conducted on Persian, Turk and Arab EFL university students. Therefore, its results may not be generalized to all EFL language learners at different proficiency levels in various educational contexts. Hence, future research could focus on learners with different levels.

5. This research used the language learning motivation questionnaire as the instrument for data collec- 
tion. Moreover, the further research could use other instruments.

\section{REFERENCES}

Alshaar E. B. (1997). Attitudes and motivation of second language learners in Kuwait. Unpublished Master's Thesis. Iowa State University, USA.

Anjomshoa, L., \& Sadighi, F. (2015). The importance of motivation in second language acquisition. International Journal on Studies in English Language and Literature (IJSELL), 3 (2), 126-137.

Bernard, J. (2010). Motivation in foreign language learning: the relationship between classroom activities, motivation, and outcomes in a university language-learning environment. Unpublished Master's Thesis. Carnegie Mellon University, USA.

Brown, H. D. (2007). Principles of language learning and teaching $\left(5^{\text {th }}\right.$ Ed.). San Francisco: Pearson Education.

Dörnyei, Z. (2005). The psychology of the language learner. Individual differences in second language acquisition. Mahwah, NJ: Lawrence Erlbaum.

Dörnyei, Z. (2001). Motivational strategies in the language classroom. Cambridge: Cambridge University Press.

Dörnyei, Z., \& Ottó, I. (1988). Motivation in action: A process model of L2 motivation. Working Papers in Applied Linguistics, Thames Valley University, London, 4(2), 43-69.

Gardner, R. C. (1985). Social psychology in second language learning: The role of attitudes and motivation. London: Edward Arnold.

Hassani, H. (2005). The relationship between intrinsiclextrinsic motivation and Iranian EFL students' gender, level of university instruction, and EFL proficienc. Unpublished M.A. Thesis, Shiraz University, Shiraz.

McNinch, J. (1997). Motivational tools in reading comprehension. Reading World, 25 (3), 243-49.

Mostafaei Alaei, M., \& Ghamari, M. R. (2013). EFL learning, EFL motivation types and national identity: In conflict or in coalition. Issues in Language Teaching (ILT), 2 (2), 85-111.

Ngeow, K. Y. (1998). Motivation and transfer in language learning. ERIC Digest. Indiana: ERIC Digests.

Razmjoo, S. A. (2010). Language and identity in the Iranian context: The impact of identity aspects on EFL learners' achievement. The Journal of Teaching Language Skills (JTLS), 2(2), 100-121.

Richards, J. C., \& Renandya, A. (2002). Methodology in language teaching: An anthology of current practice. Cambridge: Cambridge University Press.

Richards, J. C., \& Rogers, T. (2001). Approaches and methods in language teaching ( $2^{\text {nd }}$ ed.), Cambridge: Cambridge University Press.

Richards, J. C., \& Schmidt, R. (2010). Longman dictionary of language teaching and applied linguistics ( $\left.{ }^{\text {th }} \mathrm{ed}.\right)$, London: Longman (Pearson Education).

Soltani, A. (2014). Impact of ethnic background on Iranian EFL university students' intercultural sensitivity level. Procedia - Social and Behavioral Sciences, 136(4), 222-227.

Vandergrift, L. (2005). Relationships among motivation orientations, metacognitive awareness and proficiency in L2 listening. Applied Linguistics, 1(2), 70-89.

Papi, M., \& Teimouri, Y. (2012). Dynamics of selves and motivation: A cross-sectional study in the EFL context of Iran. International Journal of Applied Linguistics, 22 (3), 287-309.

Williams, M., R. L. Burden, and U. Lanvers (2002). French is the language of love and stuff: students' perceptions of issues related to motivation in learning a foreign language. British Educational Research Journal, 28 (4), 503-28.

Masgoret, A. M., and R. C. Gardner (2003) Attitudes, motivation and second language learning: A meta-analysis of studies conducted by Gardner and Associates. Language Learning 53 (1), 123-63.

MacIntyre, D., S. C. Baker, R. Clément, and L. A. Donovan (2002) Sex and age effects on willingness to communicate, anxiety, perceived competence, and L2 motivation among junior high school French immersion students. Language Learning 52 (3), 537-64.

Papi, M. (2010). The L2 motivational self-system, L2 anxiety, and motivated behavior: A structural equation modeling approach. System 38 (1), 467-479.

\title{
APPENDIXES
}

\author{
Appendix I: Motivational Questionnaire Adapted from Attitudes/Motivation Test Battery (Gardner, 1985) \\ - $\quad$ Strongly Agree $=5$ \\ - $\quad$ Agree $=4$ \\ - No Idea $=3$ \\ - $\quad$ Disagree $=2$ \\ - $\quad$ Strongly Disagree $=1$ \\ 1. I hate English. \\ 2. English is an important part of school program. \\ 3. I really enjoy learning English. \\ 4. I think that learning English is dull. \\ 5. I will try to understand all the English I see and hear. \\ 6. I do not try to understand the more complex aspects of English.
}


7. I keep up to date with English by working on it almost every day.

8. I don't bother checking my corrected assignments in my English course.

9. When I am studying English, I ignore distractions and stick to the job at hand.

10. I don't pay too much attention to the feedback I receive in my English class.

11. I really work hard to learn English.

12. I tend to approach my English homework in a random and unplanned manner.

13. When I have a problem understanding something we are learning in my English class, I always ask the instructor for help.

14. I haven't any great wish to learn more than the basics of English.

15. I want to learn English so well that it will become second nature to me.

16. Knowing English isn't really an important goal in my life.

17. I would like to learn as much English as possible.

18. If it were up to me, I would spend all of my time learning English.

19. To be honest, I really have little desire to learn English.

20. Studying English can be important to me because it will allow me to be more at ease with fellow foreigner who speak English

21. Studying English can be important for me because it will allow me to meet and converse with more and varied people.

22. Studying English can be important for me because it will enable me to better understand and appreciate art and literature of English speaking countries.

23. Studying English can be important for me because it will be able to participate more freely in the activities of other cultural groups.

24. Studying English is important for me because I'll need it for my future career.

25. Studying is important to me because I think it will someday be useful in getting a good job.

26. Studying English is important for me because it gives me the edge in competing with others.

27. Studying English is important for me, so I can pass the required courses in school.

28. Studying English is important for me, so I can pass the selected courses in school.

29. Studying English is important for me, so I can graduate from school.

\section{Appendix II. Consent letter for the Questionnaire}

Dear Participants,

The purpose of this study is to investigate beliefs among EFL learners to identify the similarities and the differences between the learners. Please complete the questionnaire below. By returning the questionnaire, you are agreeing that your responses will be part of my research project and may be cited in reports and any resulting publication. However, your identity will be kept strictly confidential

As a case you are interested to know about the findings of this research, the researcher will accept all enquiries whole-heartedly.

Thank you for your participation.

Signature- 